\title{
MED DISTANCIRANOSTJO IN ANGAŽIRANOSTJO: PROTISLOVJA POROČANJA O »BEGUNSKI KRIZI« V DNEVNEM TISKU
}

\author{
Dejan JONTES
}

COBISS 1.01

\section{IZVLEČEK}

Med distanciranostjo in angažiranostjo: protislovja poročanja o »begunski krizi« v dnevnem tisku Avtor v članku analizira poročanje o »begunski krizi« v treh osrednjih slovenskih dnevnih časopisih, Delu, Dnevniku in Večeru, v obdobju, ki so ga novinarji poimenovali "prvi in drugi begunski val«. Pri analizi se osredotoča na uokvirjanje problematike in na prevladujoče novinarske konvencije, s katerimi se uprizarja objektivnost, pri čemer skuša prikazati temeljno protislovje pri poročanju o »begunski krizi«. Na eksplicitni ravni je namreč v dnevnih časopisih problem $\mathrm{z}$ distanciranim poročanjem prevladujoče uokvirjen s humanitarno krizo, v redkih primerih tudi z varnostno grožnjo, na konotativni ravni pa se z značilnostma poročanja, kot sta faktizem in epizodičnost, utrjuje prevladujoči strah pred množičnostjo beguncev. Poleg tega v poročanju prihaja tudi do odmika od konvencij objektivnosti in bolj angažiranega poročanja, kjer dnevne novice z zatekanjem k arhetipskim podobam herojev delujejo podobno kot mit.

KLJUČNE BESEDE: begunska kriza, migracije, novinarske konvencije, kakovostni tisk, objektivnost, faktizem

\section{ABSTRACT}

\section{Between Detachment and Engagement: Paradoxes in Reporting about the "Refugee Crisis" in}

\section{Daily Press}

The paper analyses reporting about the "refugee crisis" in Slovenia's three main daily newspapers Delo, Dnevnik and Večer in the first weeks of mass migrations through the country that were named "the first and the second wave of refugees" by the journalists. The analysis focuses on the question of framing and on the dominant journalistic conventions through which objectivity is performed. The paper tries to reflect on the paradox in reporting these issues where the problem is dominantly framed in terms of humanitarian crisis on the explicit level and rarely as a security issue but on the connotative level factism and episodic framing suggest another reading of the problem that supports the fear of the imigrants. What is more, examples of more engaged reporting can be found where archetypal figures of heroes are called upon and where daily news functions similar as myth.

KEY WORDS: refugee crisis, migrations, journalistic conventions, quality press, objectivity, factism

Dr. komunikologije, docent; Univerza v Ljubljani, Fakulteta za družbene vede, Kardeljeva pl. 5, SI-1000 Ljubljana; dejan.jontes@fdv.uni-lj.si 


\section{UVOD}

Migracije so v zadnjih dveh desetletjih deležne velike medijske pozornosti, še zlasti pa se je interes za diskurze o migracijah okrepil po 11. septembru 2001, čemur je sledilo tudi povečanje raziskovalnega interesa. Ugotovitve teh študij variirajo od poudarjanja podreprezentiranosti migrantov v medijih (Sjöberg, Rydin 2014), stereotipnih vizualnih reprezentacij (Cheregi 2015) do negativnih oziroma zelo ozkih in izključujočih reprezentacij te družbene skupine. Benson (2002: 49) tako denimo ugotavlja, da se je v ZDA in Franciji med letoma 1973 in 1991 prevladujoče družbeno uokvirjanje te teme progresivno premikalo od altruističnih skrbi za družbeno dobrobit migrantov k politiki strahu. Še zlasti v Franciji se je po ugotovitvah njegove študije »ideološka leča«, skozi katero so mediji prikazovali migrante, v tem času zožila in premaknila v desno. Benson in Saguy (2005: 246) pa pokažeta, da je poročanje odvisno predvsem od "nacionalnih kulturnih repertoarjev«, povezanih s temo, in ne $\mathrm{z}$ realnostjo migracij. Tudi A. Lawlor (2015) na primeru longitudinalne študije britanskega in kanadskega poročanja o tej temi ugotovi podoben premik k sekuritizaciji in s tem povezanim strahovom, kar pa kljub temu ne postane dominantna tema, saj v poročanju še vedno prepozna tudi precejšnje variacije.

V slovenskem primeru analize poročanja o beguncih že od devetdesetih let kažejo bolj enotno sliko. Duopona Horvat, Verschueren in Žagar, ki se ukvarjajo z retoriko begunske politike v Sloveniji na primeru bosanskih beguncev, ugotavljajo, da je bilo vprašanje beguncev uspešno opredeljeno kot problem. »Z drugimi besedami, ustvarili so krizo, tako da so odkloni od nekaterih načel zlahka obveljali za izjemne ukrepe, ki sami po sebi ne spodbijajo temeljnejšega in domnevno trdnega vrednostnega sistema" (Doupona Horvat idr. 2001: 39). Podobno ugotavlja Mojca Pajnik (2007), ki je v analizo poročanja o beguncih zajela obdobje med letoma 2003 in 2005, ko se je o beguncih še vedno poročalo kot o številčno visoki grožnji, državniška drža pa se je po njenih ugotovitvah uporabljala kot legitimizacijski okvir za nekatere diskriminatorne diskurzivne obrate. Kljub temu je zaznala premike v poročanju, kot so osredotočanje na zgodbe, v katerih govorijo begunci, poročanje o težavah, s katerimi se soočajo in podobno (Pajnik 2007: 1). V nadaljevanju zato svoje ugotovitve na nekaterih mestih primerjam tudi s ključnimi ugotovitvami predhodnih študij in se pri analizi uokvirjanja nanje navezujem tudi v metodološkem pristopu.

$\mathrm{V}$ članku skušam $\mathrm{k}$ obstoječim študijam prispevati $\mathrm{z}$ analizo poročanja o »begunski krizi« v treh osrednjih slovenskih dnevnih časopisih, ${ }^{1}$ Delu, Dnevniku in Večeru, časovno pa sem se osredotočil na izbrana dva tedna $\mathrm{v}$ obdobju največjega povečanja prehodov migrantov čez državo, jeseni 2015, in sicer na začetek obdobja, ki so ga novinarji poimenovali "prvi in drugi begunski val «. ${ }^{2}$ Analiza se osredotoča na vprašanji, kako je povečan prehod

1 Poročanje $\mathrm{v}$ tabloidih in (desnem) revijalnem tisku v tem sklopu obravnavata Vezovnik (2017) in Pušnik (2017), Odmeve analizira Breda Luthar (2017), mnenjski tisk pa Mojca Pajnik (2017).

$2 \mathrm{Z}$ metaforami se v tem tekstu ne bom posebej ukvarjal, a tudi na mojem vzorcu je kljub temu treba poudariti prevlado metafore »begunskega vala«, kar ugotavljajo že pretekle raziskave, ki analizirajo poročanje o bosanskih beguncih v prvi polovici devetdesetih let prejšnjega stoletja. Doupona Horvat in drugi (2001: 20) tako poudarjajo, da »metafora begunskega vala uteleša enega najočitnejših vidikov pri konstruiranju begunske problematike - gre za gole številke, $s$ katerimi je mogoče objektivno podpreti omejitve glede tega, kaj Slovenija lahko stori. Politiki in novinarji so z združenimi močmi prikazovali podobo resničnega tveganja, da slovenska država doživi kolaps.« 
migrantov skozi državo ${ }^{3}$ uokvirjen $\mathrm{v}$ dnevnem tisku ter o delovanju prevladujočih novinarskih konvencij in $\mathrm{z}$ njimi povezanih formalnih vidikov novinarskih zgodb. Tako »kaj« pripovedi (vsebina) kot »kako" pripovedi (način izrekanja) namreč skupaj konstituirata pomen povedanega (glej tudi Jontes, Luthar 2015). Z analizo delovanja ključnih novinarskih konvencij in pomenov, ki jih te generirajo, tako dopolnjujem analizo prevladujočih medijskih okvirov. Metoda uokvirjanja, kot opozarja Reese (2003: 8), lahko kljub bolj "prefinjenemu « pristopu od tradicionalne analize vsebine enostavno zdrsne v problematično paradigmo medijskih učinkov.

\section{TEORETSKO IZHODIŠČE IN METODA}

$\mathrm{V}$ analizi treh osrednjih časnikov sem se osredotočil na obdobji med 18. in 25. septembrom in 19. in 26. oktobrom 2015, to sta prva tedna po začetku prvega in drugega obdobja množičnega prehoda beguncev skozi Slovenijo. V izbranem obdobju je bila ta tema v Delu, Dnevniku in Večeru dnevno umeščena na prvo ${ }^{4}$ stran, ki sem jo zajel v analizo, v nadaljevanju pa se na prvi strani ne pojavlja več dnevno. Poleg prispevkov informativnih zvrsti in komentarjev so bile v tem času na to temo v Delu objavljene tudi štiri karikature, ki jih nisem posebej obravnaval, sicer pa analiza zajema 50 novinarskih prispevkov. ${ }^{5}$

Tabela 1: Število analiziranih prispevkov po publikacijah

\begin{tabular}{|c|c|c|c|c|}
\cline { 2 - 5 } \multicolumn{1}{c|}{} & Delo & Dnevnik & Večer & Skupaj \\
\hline Uvodnik/komentar & 9 & 2 & 0 & 11 \\
\hline Novica (s fotografijo) & $19(14)$ & $11(9)$ & $9(9)$ & 39 \\
\hline
\end{tabular}

V analizi uokvirjanja se deloma naslanjam na pristop, ki sta ga $v$ longitudinalni študiji poročanja o migrantih v ameriškem in francoskem tisku uporabila Benson in Saguy (2005). Avtorja razlikujeta med tremi glavnimi okvirji, in sicer med problemi za migrante, problemi, ki naj bi jih povzročali migranti, ter med okvirom, ki tematizira migracije v okviru pozitivne kulturne diverzitete. V sklopu "problemi za migrante« nadalje razlikujeta med družbenim, kulturnim in rasnim/etničnim okvirom. Družbeni okvir naslavlja težave, s katerim se soočajo migranti, kot so slabe bivanjske razmere, kršenje človekovih pravic ali dostojanstva migrantov, kriminalna dejanja nad migranti, nesreče in podobno. Kulturni

3 Širši družbeni kontekst je orisan v uvodniku k temu tematskemu sklopu.

4 Zavedam se, da osredotočanje samo na prvo stran lahko ponudi do neke mere omejene rezultate, saj je tema obravnavana tudi v drugih rubrikah in prilogah izbranih časopisov, vendar pa je tako zaradi dodatne teže, ki jo nosi naslovnica, kakor tudi zaradi spremenjenih bralskih navad občinstev ključno ravno to, kako je problem uokvirjen na prvi strani.

5 Izbor člankov za analizo je bil opravljen iz vseh člankov s korenom migra*, prebež ${ }^{\star}$, begun* v obdobju med 20. 8. 2015 in 31. 12. 2015, posredoval pa jih je Urad vlade RS za komuniciranje. Po podatkih Nacionalne raziskave branosti je bil leta 2015 doseg Dela 141.000, Dnevnika 98.000 in Večera 95.000 (Valutni podatki NRB 2015). Za metodologijo Nacionalne raziskave branosti in razlago pojma »doseg« glej spletno stran raziskave: http://www.soz.si/projekti_soz/nrb_nacionalna_raziskava_branosti/valutni_podatki_nrb_2015. 
okviri vključujejo grožnje migrantom in poudarjanje emocionalne razpetosti med njihovo izvorno in prisvojeno kulturo, rasni/etnični pa vključujejo diskriminatorno obravnavo migrantov na podlagi rase ali etničnosti. Na drugi strani Benson in Saguy probleme, ki naj bi jih povzročali migranti, kodirata $v$ dve vrsti, kulturne in finančne. Kulturni okviri kulturo migrantov in njihove religijske prakse obravnavajo kot grožnjo kulturi države, v katero prihajajo, finančni okviri pa se osredotočajo na različne stroške migrantov za davkoplačevalce (glej Benson, Saguy 2005: 243). Na ravni članka sem kodiral vseh 50 analiziranih prispevkov, pri čemer sem članek v določeni okvir umestil ob eksplicitni omembi (novinarja ali vira) zgoraj opisanih problemov, rezultate pa predstavljam v nadaljevanju.

Analiza uokvirjanja je na prvi ravni pomembna, ker so okviri kognitivne strukture ter pomemben element javnega diskurza o neki temi (glej Cheregi 2015: 98). Entman (1993: 52) opredeli uokvirjanje kot proces izbire »nekaterih vidikov percipirane realnosti, s katerim se ta $\mathrm{v}$ tekstu bolj poudari in spodbuja točno določeno definicijo problema, vzročno interpretacijo, moralno oceno in/ali priporočilo za rešitev«. Reese (2003: 7) izhaja iz konstruktivistične paradigme in okvire opredeljuje kot »organizacijske principe, ki so deljeni v družbi, vztrajni skozi čas in simbolno delujejo, da bi smiselno strukturirali družbeni svet«. Lawlor (2015: 329) poudarja, da so okviri več kot pozitivne ali negativne leče, skozi katere opazujemo problem, saj so hevristični pripomočki, pridobljeni predvsem iz medijev, ki javnosti pomagajo sintetizirati in integrirati nove informacije. Pri vprašanju migracij je ta vidik še zlasti pomemben.

$\mathrm{V}$ analizi konvencij, s katero dopolnjujem analizo uokvirjanja, se osredotočam na delovanje oziroma uprizarjanje objektivnosti, ki je kljub številnim kritikam v dnevnem tisku še vedno osrednji element t. i. novičarske paradigme (glej Reese 1990; Hackett 1984). Hackett poudarja, da objektivnost in $\mathrm{z}$ njo povezana pravila nepristranskosti ne samo prikrivajo ideološka sporočila $v$ medijih, ampak so ključni del njihovega ideološkega dela. S tem ko novinarji sprejemajo "nevtralno « in distancirano poročanje kot normo, utrjujejo meje, vrednote in pravila, ki jih vzpostavljajo in interpretirajo predvsem elitni viri.

Pri tem bom izhajal iz t. i. kulturne obravnave novinarstva, ki nasprotuje prevladujočim novinarskim pojmovanjem (in je z njim pogosto neusklajeno) o tem, kako nastaja védenje in kako je lahko reprezentirano, kar je temelj novinarske samopercepcije (glej npr. Zelizer 2004). Z novinarskim diskurzom je takšen pristop nezdružljiv že v izhodišču, saj zavrača glavni novinarski mit o novicah kot bolj ali manj natančnem odsevu realnosti ter vztraja, da so novice rezultat številnih dejavnikov, od birokratskih omejitev in poklicne ideologije do številnih narativnih strategij, s pomočjo katerih novinarske zgodbe sploh nastajajo. Kulturni pristop namreč poudarja, da so, tako kot vsi drugi, tudi novinarji umeščeni v jezik in z njim do neke mere tudi konstituirani, zato njihovih percepcij in proizvodov, torej novic, ne moremo pojasnjevati zgolj v okvirih individualne avtonomije in namere (prim. Dahlgren 1992: 11; Luthar 2001).

\section{DOGODKOVNOST IN UOKVIRJANJE „BEGUNSKEGA VALA»}

Primerjalne nacionalne študije poročanja o migracijah, kot sta denimo Bensonova (2010) ali Lawlorjeva (2015), prepoznavajo vrsto z migracijami povezanih okvirov, od varnostnega, ekonomskega, zaposlitvenega, multikulturalističnega, ali okvira, ki tematizira diverziteto. V mojem vzorcu prevladujoči okvir tematizira »begunsko krizo« v okviru različnih 
družbenih problemov za migrante, kršenja človekovih pravic in humanitarne krize ter viktimizacije. ${ }^{6}$ Med tremi analiziranimi časopisi pri tem ni bistvenih razlik. Na prevlado omenjenega okvira kažejo že sami naslovi, v nadaljevanju pa navajam še nekaj tipičnih primerov takšnega uokvirjanja zgodbe:

Ob takšni tragediji bi morale pasti vse meje in pregrade. (Gaube, Roglič 2015: 1)

Begunci premraženi in dehidrirani. (Škerl Kramberger 2015: 1)

Tragični prizori Slovenijo in Hrvaško prisilili k popuščanju. (Gaube 2015: 1)

Trnova balkanska pot. Če se bodo uresničile bavarske grožnje z zaprtjem avstrijsko-nemške meje, bo to šele prava begunska kriza. (Čibej 2015: 1)

Počeni avstrijsko-slovensko-hrvaški člen na zahodnobalkanski migracijski poti je v dežju in hladnih temperaturah grenil življenje tisočim beguncev v vsaj petih državah na njihovi poti proti Nemčiji. (Gaube 2015a: 1)

Tragični prizori Slovenijo in Hrvaško prisilili k popuščanju. (Gaube 2015a: 1)

Premraženi čakajoči begunci na dežju. Pretepi za suh kotiček v šotorih. Tragični prizori so po dnevu zaostrovanj vzdolž zahodnobalkanske poti včeraj najprej Slovenijo, zatem pa še Hrvaško prisilili k popuščanju. (Gaube 2015a: 1)

Kot alternativni okvir se v posameznih izoliranih primerih v vseh treh časopisih pojavlja še varnostni okvir, ki tematizira problem $v$ kontekstu nelegalnih prehodov meje in množičnosti migrantov, ne povezuje pa ga s terorizmom ali kakšnimi drugimi kriminalnimi dejanji migrantov, kot je pogosto v desnem tisku.

Na obzorju zaostritev begunske krize? (Roglič, Gaube 2015: 1)

Vojska razširja svoja krila. (Škerl Kramberger, Roglič 2015: 1)

Prihajajo dnevi kaosa? Bilanca sinočnjega večera: solzivec na mejnem prehodu Rigonce, meddržavni incident in opozorilo z Dunaja. Razmere so se sinoči na mejnem prehodu Rigonce zaostrile. Hrvaška policija je okoli 500 beguncem odprla poti proti Sloveniji, vendar jih v Slovenijo ni spustil kordon naših policistov. (Bercko idr. 2015: 1)

Zaradi napovedi, da bo drugi begunski val bolj množičen, kot je bil septembrski, se je v soboto sestal Svet za nacionalno varnost, takoj za njim pa tudi vlada. Premier Miro Cerar je povedal, da je bilo sklenjeno, da policiji pri varovanju meje s Hrvaško lahko pomaga tudi vojska. (C. R. 2015: 1)

6 O diskurzu viktimizacije na primeru migrantskih delavcev z območja nekdanje Jugoslavije glej analizo Andreje Vezovnik (2015: 16-19). 
Čeprav ne gre za izključno negativno reprezentacijo beguncev, lahko kot zlasti problematično poudarim izjemno ozek nabor okvirov, v katerih je problem obravnavan, in $\mathrm{v}$ tej luči tudi popolno odsotnost okvira pozitivne kulturne raznolikosti, saj niti en prispevek te teme ne obravnava niti eksplicitno niti implicitno. Lahko pa na drugi strani v vzorcu kot pozitivno poudarim odsotnost t. i. neoliberalnega ${ }^{7}$ uokvirjanja problematike, ki se pri poročanju o migrantih razmeroma pogosto pojavlja $\mathrm{v}$ ameriškem tisku (Benson 2002: 58); ta migrante obravnava kot poceni delovno silo, ki prinaša ekonomsko korist.

Vsi prispevki z izjemo enega opisujejo konkretne dogodke, kar v nadaljevanju podrobneje obravnavam pri vprašanju epizodičnosti. Benson (2010: 16) poudarja, da je učinek teh okvirov ustvarjanje serije dramatičnih naracij, ki poudarjajo epizodične dogodke, kot je recimo poskus prevare ali nelegalno prečkanje meje, s tem pa se pozornost preusmerja stran od konstruktivne razprave, ki bi lahko pripeljala do bolj celostnega razumevanja konteksta politik, povezanih z migracijami. Če Lawlor (2015) pokaže, da mediji to vprašanje obravnavajo tudi kot večplastno notranjepolitično vprašanje, v mojem primeru to ni tako. Prav odsotnost kakršnih koli razprav o migracijskih politikah, z izjemo problematizacije evropskih kvot $\mathrm{v}$ komentarjih, je eden najbolj problematičnih vidikov poročanja $\mathrm{v}$ kakovostnem tisku.

V nasprotju z uokvirjanjem zgodbe kot humanitarne krize več kot polovica od 32 fotografij v vzorcu na drugi strani prikazuje predvsem nepregledne množice migrantov, pogosto s policisti ali z vojaki v ospredju. Na konotativni ravni lahko podobe množic migrantov razumemo kot grožnjo in vizualno utrjevanje varnostnega okvira. Messaris in Abraham (2003: 225) poudarjata, da slikovno uokvirjanje ni pomembno le zato, ker lahko podobe prenašajo neubesedljive pomene, ampak tudi zato, ker je zavedanje o teh pomenih še zlasti izmuzljivo. Podobe se zaradi podobnosti s stvarjo, ki jo reprezentirajo, zdijo tesneje povezane $\mathrm{z}$ realnostjo kot besede, čeprav so tudi fotografije »človeško ustvarjene umetne konstrukcije« (2003: 216). Fotografije so tako pri artikulaciji ideoloških sporočil precej bolj učinkovite kot besedilo (prim. Cheregi 2015; Messaris, Abraham 2003).

$\mathrm{Na}$ ravni novinarskih konvencij je prva in ključna značilnost analiziranih prispevkov epizodičnost ali dogodkovnost, ki pri poročanju o migrantih v resnem tisku v celoti prevladuje nad tematsko obravnavo. Na splošno dogodkovna obravnava zapostavlja družbeni kontekst problema, kar je še zlasti izrazito v našem primeru, poleg tega pa sproža drugačne interpretacije vzrokov za neki družbeni problem ter drugačno percepcijo njegovega reševanja (gl. Iyengar 1991). Vsi analizirani prispevki z izjemo enega opisujejo izključno konkretne dogodke in problema ne obravnavajo tematsko. Poleg tega je za vseh $11 \mathrm{v}$ vzorec vključenih komentarjev značilna prav dekontekstualizacija, čeprav bi kot interpretativna zvrst lahko - oziroma naj bi - ponujali prav kontekstualizacijo. Tako pa večina komentarjev »begunski val« obravnava zgolj v luči nesposobnosti evropskih držav za reševanje tega problema in posledično nesposobnosti uresničevanja »evropskih vrednot «. ${ }^{8}$

Da prevlada dogodkovnosti ni značilna samo za obdobje krize oziroma večjih ekscesov, pokaže Mojca Pajnik (2007) v analizi medijskih besedil na temo begunstva v letih 2003-2005, kjer ugotavlja, da je poročanje izrazito vezano na posamične dogodke, kot so

$7 \quad$ Za študijo novinarskega upovedovanja neoliberalizma glej Trdina, Pušnik (2010).

8 Podrobneje o mnenjskem tisku glej analizo Mojce Pajnik (2017) v tem sklopu. Andreja Vezovnik (2013: 613) tudi na primeru izbrisanih pokaže, kako je Evropa konstruirana kot idealizirano utelešenje demokratičnih vrednot, ki jih je treba zasledovati tudi v Sloveniji. 
svetovni dan beguncev, odprtje azilnega doma in podobno. Ker je percepcija nekega problema $\mathrm{v}$ javnosti $\mathrm{v}$ veliki meri odvisna od prevladujočega načina okvirjanja tega problema $\mathrm{v}$ medijih, lahko moč medijev razumemo predvsem v konstruiranju in omejevanju družbenega znanja, ta pa igra ključno vlogo tudi pri razumevanju »begunske krize«. Časopisni članki, uvodniki in druge rubrike v tiskanih medijih so javni diskurzi, v katerih se konstruirajo in reproducirajo podobe o migrantih, to konstruiranje in razpravljanje $\mathrm{v}$ javni sferi pa ni nevtralno, objektivno in apolitično.

\section{FAKTIZEM}

Druga ključna značilnost analiziranih prispevkov je faktizem, eden osrednjih strateških ritualov prevladujoče objektivistične novinarske paradigme. Strateški ritual predpostavlja, da se neka oblika poročanja uporablja nepretrgano in s stiliziranim, ponavljajočim se uprizarjanjem oblikuje tradicijo in posledično legitimnost tega delovanja/poročanja. ${ }^{9}$ Objektivnost se v novinarstvu uprizarja s pomočjo ritualiziranih praks, poklicnih kod in tekstualne konvencije objektivnega novinarstva. Resnica dogodka je tako rezultat protokolov utemeljevanja resničnosti.

Faktizem (gl. Johnson Cartee 2005: 133) se v medijih udejanja predvsem z dekontekstualiziranim nizanjem dejstev, to je s proizvodnjo dejstev, npr. anket javnega mnenja $\mathrm{v}$ časopisih, ter v rutinski in ritualizirani uporabi t. i. zunanjega glasu oz. izjav v novinarski zgodbi. Javnomnenjske ankete in avtoritativni uradni viri, ki naj bi ponujali uradna, verodostojna dejstva, sta dva osrednja strateška rituala faktizma.

Med 13 Dnevnikovimi prispevki je tako kar 18 uradnih $^{10}$ virov, največ vladnih, ${ }^{11}$ po enkrat pa kot vir nastopijo migranti, prostovoljci in predstavniki nevladnih organizacij. Zelo podobno je v Večeru, kjer je uradnih virov devet, po enkrat pa nastopijo predstavniki Rdečega križa in »običajni« ljudje. Razmerje v prid uradnim virom je najbolj izrazito v primeru Dela, kjer v 19 prispevkih informativne zvrsti kar 36-krat nastopijo uradni viri, štirikrat strokovnjaki, tri glasove so dobili "navadni« ljudje, dva begunci in enega predstavniki nevladnih organizacij. S takšno selekcijo virov je povezano tudi fetišiziranje »močnih javnosti«, kot to imenuje Mojca Pajnik (2015: 65), temu primerno pa je po njenem mnenju redukcionistično razumevanje politike.

Če Mojca Pajnik (2007: 1) v preteklih analizah zaznava premik, da namreč v novinarskih zgodbah do glasu občasno pridejo tudi begunci, v pričujočem vzorcu ti kot »vir« nastopajo le $\mathrm{v}$ peščici primerov, in še takrat $\mathrm{v}$ množini ali anonimizirani obliki.

9 Gaye Tuchman strateški ritual opredeli kot »rutinsko proceduro, ki je relativno slabo ali le bežno povezana z zastavljenim ciljem « (1972/1999: 298). Strateški ritual potrjuje tudi kolektivno izkustvo novinarjev in novinarskih organizacij ter ustvarja in predstavlja retorično legitimacijo novinarskega poklica (glej Zelizer 1993: 191).

10 Zaradi tako velike odvisnosti od uradnih virov McChesney (2002) novinarstvo imenuje kar "stenografija za uradne vire«.

11 Premier Cerar se denimo v vseh prispevkih kot vir pojavi kar 15-krat, notranja ministrica Györkös-Žnidar devetkrat in državni sekretar na Ministrstvu za notranje zadeve Šefic prav tako devetkrat. 
Mlajša farmacevtka je povedala, da v Iraku zaradi nasilja, neprestanih bojev in eksplozij ni več mogoče bivati. Četudi v Nemčiji nima nikogar, si želi tja, saj je prepričana, da ji bo tam dobro. (Sečen 2015: 1)

Kako daleč je do Avstrije, so včeraj spraševali begunci v Šentilju. (Večer 2015: 1)

»Edino, kar si želimo, je, da nadaljujemo pot skozi Slovenijo in naprej, «so si edini utrujeni obrazi, ki sta jim najpomembnejši le dve besedi: »water, Slovenija«. (Vodovnik 2015: 1)

»To je zapor, « je včeraj povedal eden od tam nastanjenih sirskih beguncev. »Ne morem poklicati družine, nimam dostopa do spleta, ne morem se preobleči, «je našteval v angleščini. Bil je v skupini, ki so jo slovenski policisti pred tednom dni prijeli blizu Lendave pri »nedovoljenem prestopu državne meje«. Tako kot preostalih trinajst je zdaj vložil prošnjo za mednarodno zaščito. »Ni bilo druge izbire. Ali vrnitev na Madžarsko, ampak tja nočem, ali pa ostati tu, « je pojasnil petintridesetletnik, po izobrazbi ekonomist. Toda raje bi šel v Avstrijo ali Nemčijo. (Zabukovec 2015: 1)

Odsotnost perspektive beguncev pride še bolj do izraza ob naslednji značilnosti faktizma, nizanju številk, ki naj bi govorile same zase. Ta pristop je značilen za vse tri časnike in veliko večino analiziranih prispevkov. Navajam zgolj nekaj izmed številnih primerov, za katere je pogosto značilno - brez kakršnegakoli konteksta - do številke natančno preštevanje migrantov ali policistov in vojakov.

Do včeraj opoldne je v državo vstopilo 6092 migrantov, od petka 19.469. Težave in huda kri so zlasti zaradi nenapovedanih prihodov iz sosednje države, kot včeraj v Rigoncah, ko je pripešačilo tisoč ljudi, za njimi pa dopoldne še nova, večja skupina. (D. R. 2015: 1)

Lani je v vsem letu v Evropsko unijo pribežalo 282.000 ljudi, letos pa jih je samo v prvih devetih mesecih evropska agencija za nadzor zunanjih meja Frontex uradno zabeležila 710.000. Od tega jih je »le« 129.000 priplulo čez Sredozemsko morje, ki je bilo prej glavna pot za prebežnike, drugi pa so prišli po balkanski poti. Septembra je po podatkih Frontexa v EU vstopilo 190.000 migrantov, kar je 20.000 manj kot mesec pred tem ... (Čibej 2015: 1)

Slovenija bo morala zdaj sprejeti 631 beguncev, kar naj bi bila po besedah ministrice Györkös-Žnidarjeve zgornja meja. (Gaube 2015c: 1)

Zadnja dva dni je mejo varovalo 731 rednih policistov in 264 pripadnikov posebne policijske enote. (C. R. 2015: 1)

Prihajajo preko rek, skozi polja koruze, po železniških tirih [...] V Slovenijo se je tudi včeraj zgrnilo več tisoč prebežnikov, večinoma z Bližnjega vzhoda, ne da bi bili naši policisti o tem predhodno obveščeni. Niso še na koncu moči, na robu pa, kot tudi na tisoče drugih - pripadnikov človekoljubnih organizacij, prostovoljcev, čisto navadnih ljudi, katerih vas in mesta so se nenadoma spremenila $\mathrm{v}$ begunsko promenado. Toda občutljivost in sočutje se delita $\mathrm{v}$ omejenih količinah - a vedno ob pravem času, smo ugotovili včeraj v begunskem centru v Šentilju, ta čas najbolj obremenjeni in frekventni točki v Sloveniji. Krivično bi bilo reči, da so prebežniki hudobni, toda nestrpni in nervozni nedvomno so. (Večer 2015b: 1) 
Kot sem že omenil, je eden ključnih mehanizmov faktizma tudi uporaba javnomnenjskih anket. Kot pravi Breda Luthar, so ankete v medijski tematizaciji problema uporabne zaradi »domnevne epistemološke jasnosti, nedvoumnosti in jedrnatosti rezultatov (54 \% za, $30 \%$ proti, $16 \%$ neopredeljenih), kjer so tako poenostavljeno artikulirana družbena nasprotja in alternative njihovih razrešitev« (Luthar 2004: 673). V mojem vzorcu je bila na prvi strani objavljena anketa, ki naj bi prikazovala visoko podporo širšim pooblastilom vojske.

Anketa Dela: Za sodelovanje vojakov na južni meji sedem desetin Slovencev.

Zadnja anketa v oktobru daje odgovor na eno večjih dilem v begunski krizi: ali naj država uporabi vojsko kot pomožno silo pri nadzoru begunskega vala [...] V anketi še izvemo, da je kljub kritikam še vedno več tistih, ki menijo, da je bila država dobro pripravljena na drugi begunski val. Slovenci so zaradi beguncev zaskrbljeni, ni pa jih strah. (Z. P. 2015: 1)

Faktizem kot osrednja novinarska konvencija objektivistične paradigme skupaj z epizodično obravnavo problema torej narekuje distancirano poročanje in dekontekstualizirano nizanje golih dejstev, ki naj bi govorila sama zase, implicitni pomen teh zgodb pa je ustvarjanje vtisa o množičnosti migrantov, s katerimi se Slovenija težko sooča, in posledično vzpostavljanje kulture strahu.

Kot poudarja Couldry (2003: 19), je osrednji paradoks, ki ga moramo dojeti, če želimo oceniti družbene posledice in moč medijev, ta, da ne moremo ločiti naših upov, mitov, občutka pripadnosti in konflikta od medijsko posredovanih oblik, v katerih se ti danes skoraj vedno pojavljajo. »Teh oblik pa ni mogoče ločiti od neenake krajine moči, iz katere izhaja medijski proces« (prav tam). Pripovedna oblika torej učinkuje na vsebino poročanja in na reprezentacijo realnosti.

Zahteva po objektivnosti in konvencije, ki objektivnost uprizarjajo, tako paradoksno predpostavljajo, da naj bi tako prepletanje različnih mnenj na koncu ustvarilo objektivni pogled na dogodek oz. problem. Elizabeth Bird (2009: 49) vidi zmanjšanje odvisnosti od uradnih virov kot enega ključnih prvih pogojev za izhod novinarstva iz (samo)deklarirane krize. Po njenem mnenju ima novinarstvo dve možnosti, in sicer se lahko oklepa tradicionalnega koncepta objektivnosti in se še naprej bori za obstanek $\mathrm{v}$ »relativističnem, ciničnem svetu, kjer zmaguje vse, kar se prodaja« (prav tam). Način »delanja novinarstva« bi lahko redefinirali predvsem $\mathrm{z}$ zmanjšanjem odvisnosti od uradnih virov, s povečanjem samostojnega poročanja ali pa $\mathrm{z}$ vključevanjem občinstva s pomočjo pomembnih, etnografskih zgodb, ki lahko ponudijo drugačna izkustva kot spletne zgodbe, dosegljive z enim klikom. 


\section{ODMIK OD USTALJENIH KONVENCIJ V ČASU KRIZE IN MITSKE PODOBE HEROJEV}

Čeprav sem v prejšnjem delu v ospredje postavil delovanje ključnih konvencij objektivnosti, se poročanje v času krize pogosto premakne v t. i. sfero konsenza (Hallin 1989), ki narekuje odmik od konvencij objektivnosti. Kot poudarja Schudson (2002: 41) v izvrstni analizi poročanja New York Timesa v prvih dneh po 11. septembru 2001, v trenutkih tragedije $\mathrm{e}^{12}$

novinarji zavzamejo pridigarsko vlogo [...] V trenutkih javne nevarnosti novinarji zamenjajo objektivnost za sosedsko tolažbo, ne glede na to, ali nevarnost prihaja od teroristov ali hurikanov. Skušajo ponuditi praktične napotke in posredovati podobne občutke. Postanejo del javne zdravstvene kampanje, ne le sistem javnega informiranja.

V takih primerih, poudarja Shudson (2002: 40), se poročanje premakne v sfero konsenza, prej distancirani novinarji pa spremenijo ton poročanja. Čeprav to v mojem primeru ni prevladujoč način, lahko kljub temu identificiram številne primere, ki razsežnost krize opisujejo z drugačnim, bolj angažiranim tonom, ne zgolj suhoparnim navajanjem številk:

Najprej tihi pogledi v daljavo proti želenemu zahodu in nato redki glasni protesti so bili vse, ves odziv ljudi iz Sirije, Iraka [...] Začelo se je dolgo nočno čakanje, ali bodo Hrvati prižgali zeleno luč za njihovo vrnitev v Zagreb. Na tamkajšnji železniški postaji pa na pot proti Sloveniji sili novih več sto obupanih. (J. Z. 2015)

Bil je čas besed, zdaj je čas dejanj. (Sečen 2015: 1)

Hallin tako poudari, da novinarji objektivnost uprizarjajo le v vmesnem krogu, v sferi legitimnega nasprotovanja. Gre za obdobje volilnega boja in zakonodajnih razprav ter za vprašanja in probleme, ki jih kot take prepoznajo uveljavljeni »igralci« v političnem sistemu. Na področju teh družbenih problemov sta objektivnost in uravnoteženost glavni novinarski vrlini. Kateri od teh modelov novinarstva prevlada, je po Hallinovem mnenju (1989: 117-118) odvisno od političnega vzdušja v državi.

Ne glede na skoraj popolno odvisnost od uradnih (vladnih) virov in nekritično reproduciranje njihovih izjav, predvsem vladajoče politike, pa je v prispevkih pogosto populistično vzpostavljanje distinkcije med »navadnimi« ljudmi in vlado/oblastjo, denimo $\mathrm{v}$ prispevku z naslovom Klanjanje Bruslju škodi domačinom in s podnaslovom Ali država razume lokalno prebivalstvo (Zore, Galun 2015: 1):

Dobovčani so vladno trojico želeli povabiti tudi na najbolj obremenjen travnik v državi. A visoka delegacija se je blatu, smetem in iztrebkom na polju - Gjorkoševa je bila v Brežicah obuta v modne teniske z nizkim podplatom - ognila. Zaradi premika novih več sto beguncev proti enemu izmed zbirnih centrov so namreč njihova vozila pred Rigoncami obrnila proti Ljubljani. (Zore, Galun 2015: 1; poudarki dodani)

12 Ob takšni tragediji bi morale pasti vse meje in pregrade, je eden izmed naslovov v Dnevniku (19. 9. 2015). 
Medtem ko bodo politiki v Bruslju danes in jutri menda zelo resno razpravljali o begunski krizi, ki je udarila po Evropski uniji, še zlasti njenem jugovzhodnem delu, navadni ljudje vedo, da so begunci tukaj - in zdaj. (Bizjak 2015: 1)

Avtorji tovrstnih prispevkov, ki tematizirajo odnos med vlado in lokalnim prebivalstvom, so najpogosteje dopisniki. Novinarji poleg tega $\mathrm{v}$ času krize namesto obravnave političnih in družbenih vprašanj pogosto črpajo tudi iz mitskih tem in arhetipskih podob (glej tudi Lule 2002). Lule loči štiri glavne vrste mitov, ki se pojavljajo v časih krize, mit, da nikoli več nič ne bo, kot je bilo, mit o žrtvah, mit o herojih ter mit o temačni prihodnosti. V našem primeru gre predvsem za reprodukcijo mita o herojih, v vlogi katerih nastopajo policisti, gasilci, prostovoljci in »običajni« ljudje:

Najtežje breme prvega vala beguncev so na slovenski strani nosili policisti in prostovoljci. Tako v Dobovi kot v Rigoncah in na Obrežju je bilo pri policistih opaziti veliko mero strpnosti, vzdržnosti in mirnosti. (Gaube 2015b: 1)

Poleg policistov so izčrpani tudi domačini. (Zore, Galun 2015: 1)

Premier Cerar svari, da Evropa ne bo zdržala, prebivalci Rigonc pa so pokazali, da lahko zdržijo in pomagajo. (D. R. 2015: 1)

Na tisoče policistov, humanitarcev in prostovoljcev gara, prebežniki pa kar rinejo naprej. Dokler bodo meje odprte. (Večer 2015: 1)

»Na voljo sem jim dala elektriko, vodo, stranišče, tudi umijejo se lahko pri meni. Danes sem jim skuhala čaj in pripravila zajtrk, " pove Ana Petrič iz Rigonc. Ko jo je novinarka vprašala, kaj bo, če ostanejo dlje, je povsem mirno povedala: »Bomo že kako.« Pa čeprav ima le 430 evrov plače. (D. R. 2015: 1)

Lule (2002: 277) opredeli mit kot družbeno zgodbo, ki izraža prevladujoče ideale, ideologije, vrednote in prepričanja. Širše gledano je mit pripoved, ki črpa iz arhetipskih figur in form, da bi ponudil zgledne modele za družbeno življenje, in je še vedno nepogrešljiv za razumevanje sveta. Številni kritiki (glej tudi Rothenbuhler 2016) tako poudarjajo, da sodobne novice pogosto delujejo kot mit, $s$ katerim pa se pojavi predvsem vprašanje njihove vloge pri vzdrževanju statusa quo v družbi. »Konec koncev je mit način upravljanja družbene spremembe« (Rothenbuhler 2016: 146).

\section{SKLEP}

V članku sem skušal pokazati, da lahko konvencije, ki so na delu pri upovedovanju »begunske krize«, generirajo protislovne pomene, saj je problem na eksplicitni ravni uokvirjen predvsem $\mathrm{v}$ terminih humanitarne krize, kršenja človekovih pravic in nespoštovanja dostojanstva, redko tudi kot varnostna grožnja, na konotativni ravni pa se s pomočjo prikazanih primerov in fotografskega gradiva utrjuje strah pred migranti. Poleg tega prihaja v 
poročanju tudi do odmika od konvencij objektivnosti in bolj angažiranega poročanja, kjer novice $\mathrm{z}$ zatekanjem $\mathrm{k}$ arhetipskim podobam herojev delujejo podobno kot mit.

Ugotovitve $\mathrm{v}$ članku so pomembne predvsem iz dveh razlogov: prvič zato, ker lahko pomembno vplivajo na percepcijo javnih politik, še zlasti na področju, kot je imigracija, kjer ljudje nimajo neposrednih izkušenj (glej Lawlor 2015: 330). Po drugi strani pa je zelo pomemben in pogosto prezrt vidik recepcija teh medijskih tekstov pri občinstvih; ta bi namreč lahko dopolnjevala tekstualne analize v tem tematskem sklopu. Sjöberg in Rydin (2014) tako na primeru Švedske na podlagi intervjujev ugotavljata, da je prevladujoči medijski diskurz zelo učinkovit pri vzdrževanju izključenosti in simbolne segregacije, namesto da bi gradil na vključenosti in spodbujanju medsebojnega razumevanja.

V kontekstu razprav o novinarstvu pa se poročanje o migracijah pogosto poenostavljeno povezuje $\mathrm{z}$ vzponom senzacionalizma. $\mathrm{V}$ tem smislu je pomenljiva Bensonova ugotovitev (2002: 58), da pri premiku uokvirjanja v smer kulture strahu komercializacija novinarstva in še zlasti komercialna televizija ne igrata osrednje vloge. Tako se pogosto posplošeno sklepa tudi v tukajšnjih obravnavah novinarstva, kjer sta političnoekonomski pogled in splošna teza o komercializaciji novinarstva ponavadi osrednja vzroka za večino težav. To tezo morda najbolj prepričljivo zavrne Bolin (2014: 345), ki trdi, da je teza o komercializaciji v veliki meri naturalizirano doksično prepričanje, saj bi morali po njegovem sile komercializacije v polju kulturne produkcije, vključno s televizijsko produkcijo, postaviti ob bok preostalim močnim silam, kot so politične, izobraževalne in podobno. Bolin tako trdi, da smo zaradi dejstva, da se je novinarstvo diverzificiralo v številne podoblike, bolj kot koncu novinarstva priča začetku obdobja hipernovinarstva (prav tam). Podobno bi seveda lahko trdil tudi v svojem primeru, zato se mi posplošene razprave o krizi novinarstva ne zdijo preveč plodne, posledično pa pri tematizaciji posameznih družbenih problemov ob veliki moči novinarskega diskurza zagovarjam kritično prevpraševanje novinarskih standardov in konvencij.

\section{LITERATURA}

Benson, Rodney (2002). The political/literary model of French journalism: Change and continuity in immigration news coverage, 1973-1991. Journal of European Area Studies 10/1, 49-70.

Benson, Rodney, Saguy, Abigail C. (2005). Constructing Social Problems in an Age of Globalization: A French-American Comparison. American Sociological Review 70/2, 233-259.

Benson, Rodney (2010). What Makes for a Critical Press? A Case Study of French and U.S. Immigration News Coverage. International Journal of Press/Politics 15/1, 3-24.

Bird, Elizabeth S. (2009). Tabloidization: What is it, and Does it Really Matter? The Changing Faces of Journalism: Tabloidization, Technology and Truthiness (ur. Barbie Zelizer). London: Routledge, 40-50.

Bolin, Göran (2014). Television Journalism, Politics, and Entertainment: Power and Autonomy in the Field of Television Journalism. Television \& New Media 15/4, 336-349.

Cheregi, Bianca Florentina (2015). The visual framing of Romanian migrants in the British television documentaries: A constructivist approach. Journal of Media Research 8/2, 96-114. 
Couldry, Nick (2003). Media Rituals: A Critical Approach. London: Routledge.

Dahlgren, Peter (1992) Introduction. Journalism and Popular Culture (ur. Peter Dahlgren, Colin Sparks). London: Sage, 1-23.

Doupona Horvat, Marjeta, Verschueren, Jef, Žagar, Igor Ž. (2001). Retorika begunske politike v Sloveniji: Pragmatika legitimizacije. Ljubljana: Mirovni inštitut.

Entman, Robert M. (1993). Framing: Towards a Clarification of a Fractured Paradigm. Journal of Communication 43/4, 5-58.

Hackett, Robert A. (1984). Decline of a Paradigm?: Bias and Objectivity in News Media Studies. Critical Studies in Mass Communication 1/3, 229-259.

Hallin, Daniel C. (1989). The Uncensored War: The Media and Vietnam. Berkeley: University of California Press.

Iyengar, Shanto (1991). Is Anyone Responsible? How Television Frames Political Issues. Chicago: The University of Chicago Press.

Johnson Cartee, Karen S. (2005). News Narratives and News Framing: Constructing Political Reality. Lanham: Rowman \& Littlefield.

Jontes, Dejan, Luthar, Breda (2015). Epistemology of journalistic rituals: The case of domestic violence. Anthropological notebooks 21/3, 21-37.

Lawlor, Andrea (2015). Framing Immigration in the Canadian and British News Media. Canadian Journal of Political Science 48/2, 329-355.

Lule, Jack (2002). Myth and Terror on the Editorial Page: The New York Times Responds to September 11, 2001. Journalism and Mass Communication Quarterly 79/2, 275-293.

Luthar, Breda (2001). Žurnalizem: Poetika skupnosti pod krinko kronologije dogodkov. Teorija in praksa 38/2, 201-212.

Luthar, Breda (2004). Ljudstvo: Navodila za uporabo (Uporaba anket javnega mnenja v novinarstvu. Teorija in praksa 41/3-4, 663-677.

Luthar, Breda (2017). Begunci in Odmevi: Epistemologija konvencij. Dve domovini / Two Homelands 45, 153-168.

McChesney, Robert W. (2002). September 11 and the structural limitations of US journalism. Journalism after September 11 (ur. Barbie Zelizer, Stuart Allan). London: Routledge, 91-100.

Messaris, Paul, Abraham, Linus (2003). The Role of Images in Framing News Stories. Framing Public Life: Perspectives on Media and Our Understanding of the Social World (ur. Stephen D. Reese, Oscar H. Gandy Jr, August E. Grant). London: Lawrence Erlbaum Associates, 215-226.

Pajnik, Mojca (2007). Medijske podobe o beguncih. Socialno delo 46/1-2, 1-11.

Pajnik, Mojca (2015). Migration in the Mirror of Mediatized Anti-politics. Razor-wired: Reflections on Migration Movements through Slovenia in 2015 (ur. Neža Kogovšek Šalamon, Veronika Bajt). Ljubljana: Mirovni inštitut, 63-70.

Pajnik, Mojca (2017). Medijsko-politični paralelizem: Legitimizacija migracijske politike na primeru komentarja v časopisu Delo. Dve domovini / Two Homelands 45, 169-184.

Pušnik, Maruša (2017). Dinamika novičarskega diskurza populizma in ekstremizma: moralne zgodbe o beguncih. Dve domovini / Two Homelands 45, 137-152.

Reese, Stephen D. (1990). The News Paradigm and the Ideology of Objectivity: A Socialist at The Wall Street Journal. Critical Studies in Mass Communication 7/4, 390-409.

Reese, Stephen D. (2003). Prologue-Framing Public Life: A Bridging Model for Media Research. Framing Public Life: Perspectives on Media and Our Understanding of the Social 
World (ur. Stephen D. Reese, Oscar H. Gandy Jr, August E. Grant). London: Lawrence Erlbaum Associates, 7-31.

Rothenbuhler, Eric W. (2016). Ritualno komuniciranje: Od vsakdanje konverzacije do medijsko posredovane ceremonije. Ljubljana: Fakulteta za družbene vede, Znanstvenoraziskovalni center SAZU.

Schudson, Michael (2002). What's unusual about covering politics as usual. Journalism after September 11 (ur. Barbie Zelizer, Stuart Allan). London: Routledge, 36-47.

Sjöberg, Ulrika, Rydin, Ingegerd (2014). Talk on the media's role in sreating otherness and exclusion: Discursive identifications and public (dis)connections. Nordic Journal of Migration Research 4/4, 201-209.

Trdina, Andreja, Pušnik, Maruša (2010). Novinarsko upovedovanje neoliberalizma: Kriza družbene kritike in pasivizacija državljanov. Teorija in praksa 47/4, 843-865.

Tuchman, Gaye (1972/1999). Objectivity as Strategic Ritual: An Examination of Newsmen's Notions of Objectivity. News: A Reader (ur. Howard Tumber). New York: Oxford University Press, 297-307.

Valutni podatki NRB 2015, http://www.soz.si/projekti_soz/nrb_nacionalna_raziskava _ branosti/valutni_podatki_nrb_2015 (20.8. 2016).

Vezovnik, Andreja (2013). Representational discourses on the Erased of Slovenia. Journal of Language and Politics 12/2, 606-625.

Vezovnik, Andreja (2015). Balkan Immigrant Workers as Slovenian Victimized Heroes. Slavic Review 74/2, 244-264.

Vezovnik, Andreja (2017). Otherness and victimhood in the tabloid press: The case of the »refugee crisis« in Slovenske novice. Dve domovini / Two Homelands 45, 121-135.

Zelizer, Barbie (1993). American Journalists and the Death of Lee Harwey Oswald: Narratives of Self-Legitimation. Narrative and Social Control: Critical Perspectives (ur. Dennis K. Mumby). London: Sage, 189-207.

Zelizer, Barbie (2004). When Facts, Truth, and Reality Are God-Terms: On Journalism's Uneasy Place in Cultural Studies. Communication and Critical/Cultural Studies 1/1, $100-119$.

\section{ANALIZIRANI VIRI}

Bercko, Vojislav, Lovrec, Vesna, Planinšič, Elizabeta (2015). Prihajajo dnevi kaosa? Večer, 19. 9., 1.

Bizjak, Sašo (2015). Eni pomagajo, eni spet razpravljajo. Večer, 22. 9., 1.

C. R. (2015). Drugi val se je usmeril na SV Slovenije. Delo, 19. 10., 1.

Čibej, Boris (2015). Strah pred zapiranjem meje in prihajajočo zimo. Delo, 20. 10., 1.

D. R. (2015). Razpad, a ne brez humanosti. Večer, 26. 10., 1.

Gaube, Aleš (2015a). Tragični prizori Slovenijo in Hrvaško prisilili k popuščanju. Dnevnik, 20. 10., 1 .

Gaube, Aleš (2015b). Slovenija znosno prenesla prvi begunski val. Dnevnik, 21. 9., 1.

Gaube, Aleš (2015c). Evropska solidarnost s preglasovanjem, begunci brez možnosti izbire. Dnevnik, 23. 9., 1.

Gaube, Aleš, Roglič, Meta (2015). Ob takšni tragediji bi morale pasti vse meje in pregrade. Dnevnik, 19. 9., 1. 
J. Z. (2015). Prvi begunski vlak na slovenski meji. Delo, 18. 9., 1.

Roglič, Meta, Gaube, Aleš (2015). Na obzorju zaostritev begunske krize? Dnevnik, 19. 9., 1. Sečen, Ernest (2015). Bil je čas besed, zdaj je čas dejanj. Dnevnik, 18. 9., 1.

Škerl Kramberger, Uroš, Roglič, Meta (2015). Vojska razširja svoja krila. Dnevnik, 21. 10., 1. Škerl Kramberger, Uroš (2015). Begunci premraženi in dehidrirani. Dnevnik, 24. 10., 1. Vodovnik, Dejan (2015). Nekoč sejmi, zdaj begunci in vlaki. Delo, 19. 9., 1.

Z. P. (2015). Podpora napotitvi vojske na mejo. Delo, 26. 10., 1.

Zabukovec, Mojca (2015). Centri neželenih. Delo, 18. 9., 1.

Zore, Janoš, Galun, Robert (2015). Klanjanje Bruslju škodi domačinom. Delo, 24. 10., 1. 


\section{SUMMARY}

\section{BETWEEN DETACHMENT AND ENGAGEMENT: PARADOXES IN REPROTING ABOUT THE "REFUGEE CRISIS" IN DAILY PRESS \\ Dejan JONTES}

The paper analyses reporting about the "refugee crisis" in Slovenia's three main daily newspapers Delo, Dnevnik and Večer in the first weeks of mass migrations through the country that were named "the first and the second wave of refugees « by the journalists. The analysis focuses on the question of framing and on the dominant journalistic conventions through which objectivity is performed. The paper tries to reflect on the paradox in reporting these issues where the problem is dominantly framed in terms of humanitarian crisis on the explicit level and rarely as a security issue but on the connotative level factism and episodic framing suggest another reading of the problem that supports the fear of the immigrants. While comparative studies highlight number of frames in news reports about immigration, in the present study the ideological focus is extremely narrow although not explicitly negative. A complete lack of discussions about immigration policy on national level is brought to fore as problematic, considerations of cultural diversity are also missing in the analysed examples. What is more, cases of more engaged reporting can be found where archetypal figures of heroes are called upon and where daily news functions similar as myth, reinforcing the status quo. In the conclusion the importance of these discourses on the perception of public policy is emphasized and reception studies of these and similar texts about refugees is suggested as an useful point for further analysis. 